\title{
Analysis on the Relevance between Yunnan Higher Vocational Education Major Layout and the Economy
}

\author{
Shiting Ding \\ $S \&$ T Office \\ Kunming Metallurgy College \\ Kunming, Yunnan, China 650033
}

\author{
Bingjing Yin \\ $S \&$ T Office \\ Kunming Metallurgy College \\ Kunming, Yunnan, China 650033
}

\author{
Xiaoju Zhou \\ PE Office \\ Kunming Metallurgy College \\ Kunming, Yunnan, China 650033
}

\begin{abstract}
Whether higher vocational education is adaptive to economic development is closely related to its major construction. This paper chooses 10 representative samples from 41 vocational colleges in Yunnan as research objects and deeply investigates their major setup. Sample selection takes type and public and private differences into consideration. This paper analyzes these samples' matching with the three main industries of Yunnan province from major setup category and stationing number, putting forward major setup and adjustment advice and principles to follow for Yunnan higher vocational education.
\end{abstract}

Keywords - higher vocational education; major construction; economic structure; relevance

\section{INTRODUCTION}

When people mention higher vocational education, besides emphasizing law of education, they pay more attention to law of the market. As higher education has the closest and most direct economic relation, currently there are many discussions on its relation with economy. In terms of discussions emphasizing correlation, there is restriction theory, interdependency theory, interactionism and so on. Of course, this kind of correlation needs no overstating, because at the same time people find that discordant phenomena of vocational education and regional economy constantly appear. For example, either the economy develops rapidly and higher vocational education lags behind relatively or the economy develops slowly and higher vocational education leads ahead relatively. The former is most outstanding in Beijing and Shanghai, whose number and new students enrollment of higher vocational college can be counted backwards nationwide. Examples of the latter are the Ningxia Hui Autonomous Region and Sichuan province. Their higher vocational education's development scale and speed is much higher than provinces and regions in the east. The above is higher vocational education's deviation from regional economic development.

\section{YUNNAN Higher VOCATIONAL EDUCATION'S DEVELOPMENT STATUS AND MAJOR SETUP}

Up to December 2016, the number of higher vocational colleges established independently in our province reaches 41 , surpassing half of the sum (68) of Yunnan's colleges and universities and forming the two-level layout: national level and provincial level. There are 2 national model higher vocational colleges, 1 national backbone college and 8 provincial model colleges ( 1 college is civilian-run) in the whole province.

Major setup becomes more and more reasonable. The whole province's higher vocational education has 19 major categories of major, covering all 19 major categories of China's higher vocational college's catalogue of specialty. There are 1200 specialties. The whole province's higher vocational colleges have 6 national classic courses, 64 characteristic specialties of provincial level(accounting for $38.1 \%$ ) and 34 important construction specialties of provincial level(accounting for $22.2 \%$ ).

\section{A. Rapid Growth in Major Number and College Scale}

From "Table I", we can see that: Kunming Metallurgy College has 72 majors and it is number one in number. Dali Nursing Career Academy and Yunnan Water Conservancy and Hydropower Career Academy respectively only have four majors, the least in number. There are 18 colleges whose enrollment majors are more than 30 , accounting for $43 \%$. The average number of major per college is 26.24 . Major growth is rapid. The following colleges are prominent in scale and speed growth: Kunming Vocational and Technical College of Industry has 15 majors in 2009 and 60 majors in 2016. The rate of increase is $390 \%$. Yunnan College of Economics and Management has 28 majors in 2009 and 59 majors in 2016. The rate of increase is $110 \%$. Yunnan Mechanical and Electrical Career Technical College has 21 majors in 2009 and 32 majors in 2016. The rate of increase is 50\%. Yunnan 
Jiaotong College has 36 majors in 2009 and 52 majors in 2016. The rate of increase is $40 \%$.

TABLE 12016 MAJOR SETUP QUANTITY STATISTICS OF HIGHER VOCATIONAL COLLEGES IN YUNNAN PROVINCE

\begin{tabular}{|c|c|c|c|}
\hline Name of college & $\begin{array}{l}\text { Number } \\
\text { of major }\end{array}$ & Name of college & $\begin{array}{l}\text { Number } \\
\text { of major }\end{array}$ \\
\hline $\begin{array}{l}\text { Kunming Metallurgy } \\
\text { College }\end{array}$ & 72 & $\begin{array}{l}\text { Yunnan Forestry } \\
\text { Technological College }\end{array}$ & 32 \\
\hline $\begin{array}{l}\text { Qujing Medical } \\
\text { College }\end{array}$ & 22 & $\begin{array}{l}\text { Yuxi Agriculture } \\
\text { Vocation Technical } \\
\text { College }\end{array}$ & 29 \\
\hline $\begin{array}{l}\text { Baoshan College of } \\
\text { Traditional Chinese } \\
\text { Medicine }\end{array}$ & 12 & $\begin{array}{l}\text { Yunnan Vocational } \\
\text { College of Judicial } \\
\text { Police }\end{array}$ & 13 \\
\hline $\begin{array}{l}\text { Chuxiong Medical } \\
\text { And Pharmaceutical } \\
\text { College }\end{array}$ & 12 & $\begin{array}{l}\text { Yunnan Sports } \\
\text { Vocational College }\end{array}$ & 13 \\
\hline $\begin{array}{l}\text { Dehong Teachers } \\
\text { College }\end{array}$ & 29 & $\begin{array}{l}\text { Yunnan Tin Career } \\
\text { Technical College }\end{array}$ & 11 \\
\hline $\begin{array}{l}\text { Lijiang Teachers } \\
\text { College }\end{array}$ & 50 & $\begin{array}{l}\text { Yunnan Economic and } \\
\text { Trade Foreign Affairs } \\
\text { Career } \\
\text { Academy(civilian-run) }\end{array}$ & 39 \\
\hline $\begin{array}{l}\text { Yunnan Vocational } \\
\text { Institute of Energy } \\
\text { Technology }\end{array}$ & 30 & $\begin{array}{l}\text { Dehong Career } \\
\text { Academy }\end{array}$ & 31 \\
\hline $\begin{array}{l}\text { Yunnan Science and } \\
\text { Technology } \\
\text { Information Career } \\
\text { Academy(civilian- } \\
\text { run) }\end{array}$ & 36 & $\begin{array}{l}\text { Yunnan Sanxin Career } \\
\text { Technical } \\
\text { College(civilian-run) }\end{array}$ & 27 \\
\hline $\begin{array}{l}\text { Yunnan Vocational } \\
\text { College of } \\
\text { Territorial Resources }\end{array}$ & 27 & $\begin{array}{l}\text { Kunming Health } \\
\text { Career } \\
\text { Academy(civilian-run) }\end{array}$ & 11 \\
\hline $\begin{array}{l}\text { Kunming Vocational } \\
\text { College of } \\
\text { Arts(civilian-run) }\end{array}$ & 28 & $\begin{array}{l}\text { Yunnan Modern } \\
\text { Career Technical } \\
\text { College(civilian-run) }\end{array}$ & 36 \\
\hline $\begin{array}{l}\text { Xishuangbanna } \\
\text { Vocational and } \\
\text { Technical Institute }\end{array}$ & 30 & $\begin{array}{l}\text { Yunnan College of } \\
\text { Tourism Vocation }\end{array}$ & 30 \\
\hline $\begin{array}{l}\text { Yunnan New Career } \\
\text { Academy(civilian- } \\
\text { run) }\end{array}$ & 23 & $\begin{array}{l}\text { Yunnan Business } \\
\text { Career } \\
\text { Academy(civilian-run) }\end{array}$ & 19 \\
\hline $\begin{array}{l}\text { Yunnan Vocational } \\
\text { and Technical } \\
\text { College of } \\
\text { Agriculture }\end{array}$ & 33 & $\begin{array}{l}\text { Yunnan Foreign } \\
\text { Affairs Foreign } \\
\text { Language Career } \\
\text { Academy(civilian-run) }\end{array}$ & 28 \\
\hline $\begin{array}{l}\text { Yunnan Jiaotong } \\
\text { College }\end{array}$ & 52 & $\begin{array}{l}\text { Honghe Health Career } \\
\text { Academy }\end{array}$ & 15 \\
\hline $\begin{array}{l}\text { Yunnan Vocational } \\
\text { College of Culture } \\
\text { and Art }\end{array}$ & 15 & $\begin{array}{l}\text { Dali Agriculture and } \\
\text { Forestry Career } \\
\text { Technical College }\end{array}$ & 16 \\
\hline $\begin{array}{l}\text { Yunnan Industry and } \\
\text { Commerce } \\
\text { College(civilian-run) }\end{array}$ & 52 & $\begin{array}{l}\text { Yunnan Finance and } \\
\text { Economics Career } \\
\text { Academy }\end{array}$ & 5 \\
\hline $\begin{array}{l}\text { Kunming Vocational } \\
\text { and Technical } \\
\text { College of Industry }\end{array}$ & 60 & $\begin{array}{l}\text { Kunming Railway } \\
\text { Career Technical } \\
\text { College(Established in } \\
\text { April 2016) }\end{array}$ & 5 \\
\hline $\begin{array}{l}\text { Yunnan Engineering } \\
\text { Career } \\
\text { Academy(civilian- } \\
\text { run) }\end{array}$ & 30 & $\begin{array}{l}\text { Zhaotong Health } \\
\text { Career } \\
\text { Academy(Established } \\
\text { in April 2016) }\end{array}$ & 5 \\
\hline $\begin{array}{l}\text { Yunnan North } \\
\text { American } \\
\text { Vocational }\end{array}$ & 16 & $\begin{array}{l}\text { Dali Nursing Career } \\
\text { Academy(Established } \\
\text { in April 2016) }\end{array}$ & 4 \\
\hline
\end{tabular}

\begin{tabular}{|l|l|l|l|}
\hline \multicolumn{1}{|c|}{ Name of college } & $\begin{array}{l}\text { Number } \\
\text { of major }\end{array}$ & Name of college & $\begin{array}{l}\text { Number } \\
\text { of major }\end{array}$ \\
\hline College(civilian-run) & & & \\
\hline $\begin{array}{l}\text { Yunnan Mechanical } \\
\text { and Electrical Career } \\
\text { Technical College }\end{array}$ & 32 & $\begin{array}{l}\text { Yunnan Water } \\
\text { Conservancy and } \\
\text { Hydropower Career } \\
\text { Academy(Established } \\
\text { in April 2016) }\end{array}$ & 4 \\
\hline $\begin{array}{l}\text { Yunnan Economics } \\
\text { and Management } \\
\text { College(civilian-run) }\end{array}$ & 59 & \multicolumn{2}{|c|}{ Note: based on various colleges' admission regulation of 2016. } \\
\hline
\end{tabular}

The above data shows that: A batch of higher vocational colleges with large scale and rapid development have formed in Yunnan province. Seeing from the speed of major growth, it is clear that: Two national model colleges have unparalleled advantages in fund, policy and so on, obtaining rapid development in construction in a short period of time. Some civilian-run colleges, like Yunnan College of Economics and Management, Einsun Career Technical College and Yunnan Economic and Trade Foreign Affairs Career Academy, also obtain great development through flexible school-running mechanisms and financing channels.

\section{B. Major Structure Is Basically Adaptive to Development of Three Major Industries in Yunnan Province, but Their Matching Degree Is Not High}

In order to discuss adaptability of Yunnan province's higher vocational education to its regional economic development more deeply and in a more detailed way, the research group chooses 10 representative higher vocational colleges to do researches, respectively are: Two national model colleges: Yunnan Jiaotong College and Kunming Metallurgy College; one national backbone higher vocational college: Yunnan Mechanical and Electrical Career Technical College; one Yunnan provincial model college: Xishuangbanna Vocational and Technical Institute; two civilian-run higher vocational colleges: Einsun Software Career Technical College(Yunnan College of Business Administration) and Yunnan College of Economics and Management; two ordinary vocational colleges: Yunnan Vocational Institute of Energy Technology and Qujing Medical College; two normal colleges: Dehong Teachers College and Lincang Teachers College. Sample selection takes difference in type and level and difference between public and private into consideration.

Yunnan's industry structure adjustment obeys the principle of three industries' "Three two one" sequence. Make the tertiary industry big, make the secondary industry strong and optimize the primary industry [4]. According to Yunnan province's "The 12th Five-Year Plan", structural relation of primary industry, secondary industry and tertiary industry in national economy had better be 15:40:45. Major structure of 10 colleges is basically adaptive to development of three major industries. But distribution of major in three industries is unbalanced, industry's internal major structure is not optimized and characteristic specialty group is not prominent. 
TABle 2 Top 15 Majors of SAmple Higher Vocational Colleges in 2016

\begin{tabular}{|c|c|c|c|c|}
\hline Ranking & Major name & Category & $\begin{array}{c}\text { Number } \\
\text { of } \\
\text { colleges }\end{array}$ & $\begin{array}{l}\text { Set } \\
\text { rate }\end{array}$ \\
\hline 1 & $\begin{array}{l}\text { computer } \\
\text { application } \\
\text { technology }\end{array}$ & $\begin{array}{l}\text { electronic } \\
\text { information }\end{array}$ & 9 & $90 \%$ \\
\hline 2 & accounting & $\begin{array}{l}\text { finance and } \\
\text { economics }\end{array}$ & 8 & $80 \%$ \\
\hline 3 & $\begin{array}{l}\text { logistics } \\
\text { management }\end{array}$ & $\begin{array}{l}\text { finance and } \\
\text { economics }\end{array}$ & 7 & $70 \%$ \\
\hline 4 & $\begin{array}{l}\text { business(economic } \\
\text { ) management }\end{array}$ & $\begin{array}{l}\text { finance and } \\
\text { economics }\end{array}$ & 7 & $70 \%$ \\
\hline 5 & artistic designing & fine arts & 6 & $60 \%$ \\
\hline 6 & $\begin{array}{l}\text { applied } \\
\text { English/business } \\
\text { English }\end{array}$ & $\begin{array}{l}\text { language } \\
\text { culture }\end{array}$ & 5 & $50 \%$ \\
\hline 7 & $\begin{array}{l}\text { automotive } \\
\text { application } \\
\text { technology }\end{array}$ & manufacturing & 5 & $50 \%$ \\
\hline 8 & $\begin{array}{l}\text { mechanical and } \\
\text { electrical } \\
\text { integration }\end{array}$ & manufacturing & 3 & $30 \%$ \\
\hline 9 & $\begin{array}{l}\text { architectural } \\
\text { engineering }\end{array}$ & $\begin{array}{l}\text { civil } \\
\text { engineering and } \\
\text { architecture }\end{array}$ & 3 & $30 \%$ \\
\hline 10 & $\begin{array}{l}\text { horticultural } \\
\text { techniques }\end{array}$ & $\begin{array}{l}\text { agriculture and } \\
\text { forestry }\end{array}$ & 3 & $30 \%$ \\
\hline 11 & applied Thai & $\begin{array}{l}\text { language } \\
\text { culture }\end{array}$ & 3 & $30 \%$ \\
\hline 12 & $\begin{array}{l}\text { electrical } \\
\text { automation }\end{array}$ & manufacturing & 3 & $30 \%$ \\
\hline 13 & $\begin{array}{l}\text { machinery } \\
\text { manufacturing and } \\
\text { automation }\end{array}$ & manufacturing & 3 & $30 \%$ \\
\hline 14 & $\begin{array}{l}\text { tourism } \\
\text { management }\end{array}$ & tourism & 3 & $30 \%$ \\
\hline 15 & $\begin{array}{l}\text { engineering survey } \\
\text { technology }\end{array}$ & $\begin{array}{l}\text { resource } \\
\text { development } \\
\text { and surveying }\end{array}$ & 3 & $30 \%$ \\
\hline
\end{tabular}

From "Table II", we can know: Top 15 majors in concentration ratio respectively are: computer application technology, accounting computerization, logistics management, artistic designing, business administration, applied English and so on, forming several major specialty groups of electronic information, finance and economics, manufacturing, communication and transportation and so on. It is not difficult to find that electronic information, cultural education, finance and economics and so on occupy top 5. Most of these majors are related to the tertiary industry, reflecting rapid development of tertiary industry with industry structure adjustment of Yunnan province. Correspondingly, Yunnan province's higher vocational colleges experience a deep transformation from industrial society to service society. The need for highly skilled talents in electronic information and finance and economics becomes increasingly strong. However, with more than 10 years' development, tertiary industry's hot majors reach a saturation value in stationing number and new students enrollment, such as accounting, secretary, computer application, business administration, electronic commerce and so on. These are once "white-collar" majors run after by students. When obtaining employment, they find that hot majors are very cool. Employer has generally higher requirements in education background for persons on these posts. Therefore, these several majors need to reduce the number of students in enrollment to avoid conflicting with majors of the same kind in undergraduate universities.

In fact, according to researches of Li Guanlin and Ren Wangbing (2003) [3], it is proved that: Employment absorbing space of China's tertiary industry has shrunk greatly. It reduces from the primary high space and continues to the current shrinkage. Employment growth track becomes a parabola. The reason is that: Since 2001, China's tertiary industry structure's degree of deviation has surpassed the level of international standard mode. If there is no appearance of new service need, it will be very difficult to enhance tertiary industry's employment absorbing capability based on current industrial needs.

One is over-high concentration ratio of hot major, and the other is scarcity of agricultural talents. Table 2 reflects that: These 10 colleges have few majors concerning agriculture, forestry, animal husbandry and fishery. Only 3 colleges have majors concerning agriculture. Among top 15 majors, only the major of horticultural techniques is related to agriculture. Other colleges also have few agriculture and forestry majors, like: Xishuangbanna Vocational and Technical Institute has horticultural techniques major and plant protection major; Dehong Teachers College has majors of horticultural techniques, Crop production technology and biotechnology application; Lincang Teachers College has majors of tea production and processing technology, facility agricultural technology, seed production and management and so on. However, proportion of stationing number and new student $\mathrm{s}$ enrollment of majors in primary industry is very small, severely disagreeing with the standard percentage of $15 \%$ in Yunnan province. Agronomy majors have been unpopular for many years. But, with great development of urbanization and rise of agricultural model garden and vegetable basket project, agricultural intensification and commercial process have a large demand for talents. Compared with highly competitive hot majors, agronomy majors have a wider employment prospect.

At the same time, as backbone specialty group, majors of manufacturing, civil engineering, resource development and surveying and mapping have a low integrating degree with five leading industrial clusters in secondary industry of Yunnan province, namely tobacco, modern energy, basic raw material, bio-processing and equipment manufacturing. Only 1 to 2 colleges set some majors, like numerical control technique, die design and manufacturing, metallic material and heat treatment technique, geographic information and cartographic technology, metallurgical technology and so on. Few colleges have relative majors of these four emerging industries: new energy, photoelectron, new material and bioindustry, and stationing number of these majors is even zero.

\section{Appropriate Advanced Grasp of Industry and Market Hot Spots in Major Setup}

Aiming at chances brought by accelerated construction of important bridge towers' opening up to southwest by ASEAN free trade area and Yunnan province, 10 higher vocational 
colleges correspondingly add some relevant majors, like: 2 colleges set up majors of exhibition economy and management, and customs clearance and international freight. Generally speaking, corresponding occupation posts of emerging industry or newly emerged industries in regional industry structural adjustment have good career prospects in higher vocational college's cultivation period. However, future employment stability remains to be tested by time.

Vigorous growth in construction of urban light rail in Kunming leads to development of urban mass transit major in colleges and universities of Kunming. According to data: Based on the international practice that every kilometer of subway needs 64 professional workers on posts of operation, management, maintenance and so on, after Kunming completes construction of the 90 kilometers' light rail in 2014, 5760 professional staff are needed. Facing such huge talent demand, among these 10 colleges, Kunming Metallurgy College and Yunnan Jiaotong College successively set up majors of urban rail transit vehicle and urban railway system and control in 2009.

Major can get close to market, but it should avoid blind pursuit of and rushing into hot spots. Besides considering social need, colleges should consider more about their own conditions in major setup so as to obtaining enough power for subsequent development.

\section{SUGGESTIONS ON DOCKING OF HIGHER VOCATIONAL EDUCATION'S MAJOR LAYOUT AND ECONOMIC STRUCTURE OF YUNNAN PROVINCE}

\section{A. Enlarge Major Proportion of Primary Industry and Pay Attention to Optimization of Structure}

Although primary industry is ancient and traditional, intensive agriculture and industrial production are still in a preliminary stage with rapid growth and large space of development. As vegetable kingdom and animal kingdom, Yunnan province has natural resource advantage in researches on agriculture and forestry and animals. Specialty related to agriculture is no longer "unreasonable" and it no longer gets away from city. The landscape architecture design major derived from forestry, flow planting major separated out from botany, brewing major deduced from food engineering, and pet care major separated out from animal medicine are fashionable and modern emerging majors.

With hot sell of agronomy graduates, students and parents change their view about these unpopular majors in former days gradually and students registering for examination of agronomy majors increase on a yearly basis. With modernized development of agronomy, its family members become more and more and it has more and more majors corresponding to employment. Higher vocational colleges with background of agricultural industry and some prefecture-level comprehensive colleges in Yunnan can add and expand agronomy majors, optimize their internal structure and weed out some majors with capacity falling behind so as to satisfy primary industry's development in Yunnan province. For example, Yunnan's flower industry expands in scale and remains the first nationwide in consecutive years, indicating that cultivation of flower plantation talent will be popular in a long time.

\section{B. Strengthen Specialty Group Construction of Pillar Industry and Develop Characteristic Specialty Groups}

Higher vocational college's backbone specialty group and secondary industry are not matching, disagreeing with Yunnan province's need to make secondary industry strong. Seeing from specialty group's adaptation to Yunnan province's five major key industries: tobacco, biological resources development and innovation industry, nonferrous metal mining, phosphorus chemical industry and electric power, colleges' current backbone specialty groups of manufacturing, civil engineering, resource development and mapping and surveying are small in scale in terms of student enrollment and stationing number. Very few colleges set up relevant majors of nonferrous metal mining and phosphorus chemical industry. Biological resources development, innovation industry and other majors with Yunnan features are almost blank.

It is higher vocational education major construction's inevitable choice to strengthen construction of pillar industry majors, fill in gaps of blank majors and develop specialty groups with Yunnan features on this basis.

\section{Combine Emerging Industries and Regional Economy and Expand New Professional Field}

At the same time of greatly developing tertiary industry, we need to pay attention to rationality of internal structure and dig out new industrial needs. In order to avoid "homogeneous competition", higher vocational colleges should pay close attention to major's degree of concentration, develop scarce majors, avoid setting up popular majors with low cost and high repetition rate, and form characteristic specialty groups. In March 2010, Ministry of Education issues a document (The Letter of Ministry of Education (2010) No.13) on declaration and approval work of college's strategic relevant majors of emerging industries and provides relevant policy support of priority approval and so on.

Throughout major setup of Yunnan's 41 higher vocational colleges, there are some majors of emerging industrial field, but the number is small. Special need of emerging industries and construction of "bridge tower" towards southwest bring about some new talent needs, like large demand of professional talents in logistics, foreign tourism, law of ASEAN countries, international commerce and trade, bond, exhibition and non-universal languages. All these provide new ideas for Yunnan's higher vocational colleges to set up and adjust majors.

\section{SEVERAL PRINCIPLES FOR MAJOR SETUP AND ADJUSTMENT}

\section{A. Combine Manifest Need with Potential Need}

A major's development needs accumulation of time to become mature. Major setup shouldn't just pursue short-term hot spots. In order to avoid going with the stream and stepping off the deep end, we should pay attention to combination of manifest need and potential need in major planning and 
development. In regional economy, due to unintelligibility and ambiguity, potential industrial need usually can't get approval from market in a short period of time. But it hides huge potential market demand. Major setup is the same. There should be scientific foreseeability for major. We should plan and set up majors strategically instead of setting up majors in a hurry way according to manifest need. The latter type of major setup lacks historical accumulation and stability of vocational need.

Generally speaking, new majors experiencing repeated demonstrations of experts on the basis of combination of social need and college's teaching advantages have relatively good prospects. Talent cultivation and major construction can't seek quick success and instant benefits. Social need is a complex, rapidly changeable and dynamic system. Present unpopular spot may become a hot spot in future, and today's hot spot may become tomorrow's "thorny sweet potato". This is a kind of caution for short-term behavior of some higher vocational colleges in major setup. If colleges go all the way to meet social needs and set up those so-called popular majors without considering their own conditions, their foundation will be unstable and they will face the awkwardness of saturation and disorder.

\section{B. Promote Both Flexibility and Stability}

Higher vocational education takes occupation and posts as guidance, regards major as footstone and emphasizes technology. Thus, it gradually weakens discipline, breaks down discipline education system of undergraduate colleges, reflects particularity of vocational education, and has more flexibility.

There's no making without breaking. But the breaking here is not total abandoning. Higher vocational education can't falls into the fundamental mire of "priority of major" and neglect of disciplinary construction. Major comes after discipline and discipline is the backup force of major. Discipline provides "nutrition" for development of major construction -- new knowledge, new skills and new results. In the process of cultivating applied talents, the function of discipline is indirect. But the role of disciplinary construction is irreplaceable in major positioning, specialty caliber, cultivation objective, teaching plan, teaching content, textbook compilation and practical training design. Without disciplinary construction, there won't be long stability of major. Otherwise, major can only go with the stream.

Based on researches on majors of Yunnan's higher vocational colleges, we find that: Some colleges form their own backbone specialty groups, reflecting their school's teaching advantages and features. These backbone specialty groups rely on their school's advantage discipline, such as: Yunnan Jiaotong College's majors of road and bridge engineering technology, vehicle application technology, application and maintenance of construction machinery and so on, and their specialty groups; Kunming Metallurgy College's majors of metallurgy technology, techniques of surveying and mapping engineering, environmental monitoring and treatment technology and so on, and their specialty groups; Einsun
Career Technical College's major of information engineering technology and its specialty group.

Major construction should obey social need, industrial development and education law in combination with its own school's disciplinary construction and teaching resource. Only by having core majors as the big plenteous tree, can branches be produced. We should emphasize both flexibility and stability and form a well-planned and complete specialty system.

\section{Unification of Specialty and Compound}

At the beginning of setup, almost all majors face the problem of balance between universality and specifity, which is vividly described as major's wide caliber and narrow caliber. It is undoubted that: Major with wide caliber can cover more vocational posts and major with narrow caliber has more pertinence and features.

Wide caliber isn't equal to high employment rate. Compound major brings large imagination space, but it is difficult to match the fact under great reputation. Apart from traditional compound majors, like: e-commerce, business administration and so on, some new compound majors appear and they are more appealing. Take compound majors in these 10 colleges' enrollment catalogue as examples, there is secretary(network communication writing direction), applied Thai(business direction), environmental art design(landscape design direction), and applied English(preschool education direction).By adding a bracket behind the major and writing $\mathrm{XX}$ direction in it, one major is combined with another major abruptly. How much gold content is there in this kind of compound major?

Some majors facing future posts in social public management department and enterprises' management department can become compound while some majors needing to highlight technicality and professionalism should be subdivided. Compound can't just be "repetition" without "combination". Subdivision of major can't be just "division" without "refineness". Unification of specialty and compound should be achieved.

\section{CONCLUSION}

Based on vocational education's special law, it is enslaved to regional economy and can properly surpass limitation of time and space. Therefore, it is normal pattern of manifestation for it to be in coordinate or discordant development with regional economy. Major is regarded as the connector of higher vocational education and society. Whether an area's vocational education can fully play its function in regional economic service or its adaptation degree to regional economy is greatly influenced by major to some extent.

\section{REFERENCES}

[1] Huang Lizhi, Li Mingliang. Research Review on Coordinate Development of China's Vocational Development and Regional Economic Development in Five Years[J]. Vocational and Technical Education: NPC Copy Newspaper and Journal Material, 2010 (10): 28-31. 
[2] Yan Lizhi, Zhu Shuanghua. Analysis on Basic Thought on Major Setup of Higher Vocational Education[J]. Vocational \& Technical Education Forum, 2008 (1) : 40-44.

[3] Li Guanlin, Ren Wangbing. Expanded Difficulty in Employment Growth in China's Tertiary Industry -- Seeing Employment Growth in China's Tertiary Industry from Evolution Track of Its Structural Deviation and International Comparison, Economics of Finance and Trade 2003 (10) : 12-14.

[4] Jiao Lirong. Yunnan Industrial Structure Adjustment and Employment Growth Relevancy Analysis, Securities \& Futures of China, 2010 (2) : 109-110.

[5] Miao Ningling. Research on Docking of Higher Vocational Colleges' Major Setup and Industrial Structure[J]. Changzhou College of Information Technology Journal, 2015, 14(2): 1-2.

[6] Tao Hong, Liao Huiqin. Research on Docking of Higher Vocational Colleges' Major Setup and Industrial Structure of Guangdong Province[J]. Vocational \& Technical Education Forum, 2016(18): 40-44.

[7] Zhang Qing, Zhou Junhua, Xiong Jianmin. Research on Docking of Higher Vocational Colleges' Major Setup and Industry of Hubei Province[J]. Contemporary Continuing Education, 2014(2): 51-54. 